\title{
Australian Journal of \\ In vitro cultivation of Mouriri elliptica (Mart.) a species with alimentary and medicinal potential using alternative to agar media
}

\author{
Elisvane Silva de Assis ${ }^{1}$, Aurélio Rubio Neto ${ }^{{ }^{*}}$, Fabiano Guimarães Silva ${ }^{1}$, Letícia Rigonato de Lima ${ }^{1}$, Paulo \\ Dornelles $^{1}$, Sebastião Carvalho Vasconcelos Filho ${ }^{1}$, Mariluza Silva Leite ${ }^{2}$, Eduardo da Costa Severiano ${ }^{1}$ \\ ${ }^{1}$ Federal Institute of Education, Science and Technology of Goiás, Rio Verde Campus, Rod. Sul Goiana Km 01, Cx. P. \\ 66. CEP 75.901-970, Rio Verde - Goiás, Brazil \\ ${ }^{2}$ State Secretary of Education of Goiás. Av. Anhanguera, 7171 - St. Oeste, CEP. 74110-010, Giânia, Goiás, Brazil
}

*Corresponding author: aurelionetorv@gmail.com

\begin{abstract}
Alternative supports can be successfully used in place of agar for in vitro culture to increase seedling vigor. The objective of the present study was to evaluate the efficiency of alternative support materials compared to agar in the in vitro cultivation of Mouriri elliptica (Mart.) in the absence or presence of naphthalene acetic acid (NAA). The alternative support materials used were mediumgrain vermiculite, sugarcane (Saccharum spp. L.) bagasse and queen palm fiber [Syagrus romanzoffiana (Chamisso) Glassman]. For this, young plants with at least two axillary buds under in vivo conditions were transferred to in vitro condition considering four replications with three young plants. After 45 days was evaluated the growth and anatomical explant characteristics. Autoclaving these alternative supports without the media and proceeding the explant desinfestation was an efficient method to contamination control and plant growth in a in vitro condition. No differences were observed between agar, vermiculite and sugarcane bagasse cultures for most growth characteristics evaluated. Greater numbers of adventitious and secondary roots and greater root length were significantly observed in plantlets grown in the presence of vermiculite and the absence of naphthalene acetic acid. In the agar culture, roots had weak points and poorly differentiated tissues, with parenchymal tissue predominating. The addition of 2.0 $\mathrm{mg} \mathrm{L}^{-1}$ naphthalene acetic acid used did not stimulate rooting in this specie. So, other auxin source and concentrations should be evaluated in future studies. Both support materials used, vermiculite and sugarcane bagasse, representing promising agar substitutes to obtain seedlings with roots.
\end{abstract}

Keywords: Anatomical characteristics, melastomataceae, micropropagation, rooting.

Abbrevations: AS_aeration space; AW_available water; Ca_callus; Di V E_disorganized vascular cambium; DD_dry bulk density; Me_medulla; NAA_naphthalene Acetic Acid; Pa_parenchyma; RW_remaining water; Ro_root; TP_total porosity; VE_vascular cambium; V C_vascular cylinder; WD_Wet bulk density; Xy_xylem.

\section{Introduction}

Mouriri elliptica (Mart.) (Melastomataceae) is a tree typical of the Cerrado domain (Brazil) and is popularly known as coroa de frade (friar's crown), croada or croadinha and puçá ou puçazeiro. In addition to its importance to the forest, its fruits rich in nutrient and antioxidant compounds have been recommended for human consumption (Rufino et al., 2011) and its trunk and leaves can be used medicinally to treat gastric ulcers and gastritis (Moleiro et al., 2009). This species was listed in the manuscripts and publications of the Scottish medic and naturalist George Gardner (1812-1849) us Ethnopharmacological relevance (Fagg et al., 2015).

Pioneering studies, such as those by Vasconcelos et al. (2010) and De Lima et al. (2016), reported the difficulty of producing $M$. elliptica (Mart.) seedlings from seeds, justifying the use of alternative methods for mass propagation. The micropropagation technique is a viable tool to produce seedlings of wild or domesticated species that are difficult to propagate by conventional methods or accelerate plantlet production (Assis et al., 2012; Martendal et al., 2014; Mali and Chavan, 2016) our conservation of endangered species (Patel et al., 2014).

In micropropagation, agar is the most widely used support material for explants in culture medium. However, problems have been reported in plantlets grown in agar medium, such as poor root formation, resulting in losses (Xiao et al., 2011). These observations, coupled with the abundant use of agar, make this agent costly for in vitro multiplication (Braga et al, 2011; Aggarwal and Nirmala, 2012; Deb and Pongener, 2013). Thus, alternative support materials that can reduce production costs and possibly improve plantlet vigor, facilitating their acclimatization, have been tested (Mohan et al., 2005; Saldanha et al., 2014).

The suitability of the culture medium and the use of growth regulators are fundamental to the induction of cellular division and root differentiation (Navarro-García et al., 2016; Abdulmalik et al., 2012). IBA (indole-3-butyric acid), IAA (indole-3-acetic acid) and NAA (naphthalene acetic acid) are 
the auxins generally used for in vitro rooting of plants (Barpete et al., 2014).

The endogenous auxin level greatly influences root induction, and the application of plant growth regulators can significantly increase either low or high concentrations of auxin (Hossain and Urbi, 2016). In some cases (Arachis paraguariensis Chodat and Hassl), these additives negatively affect micropropagated plantlets (Aina et al., 2015). For some species in vitro rooting acclimatization aiming torn-ase unnecessary (Shekhawat and Manokari, 2016). Studies of the interaction between growth regulators and culture medium support materials have been rare and are of extreme importance.

The first study on vegetative propagation of M. elliptica (Mart.) by means of tissue culture was conducted by Assis et al. (2016), in which, it was possible to produce plantlets in traditional and photoautotrophic culture conditions by increasing the irradiance (50 to $150 \mu \mathrm{mol} \mathrm{m} \mathrm{m}^{-2}$ ) in the environment. However, the importance of developing new methods associated with the photoautotrophic system that enhance the in vitro production of seedlings of this species was discussed, citing the use of materials as alternative supports to agar focused on plantlet rooting, ending the in vitro propagation protoco. Thus, this study sought to evaluate the effectiveness of support materials alternative to agar for the in vitro rooting of plantlets of this species in the presence or absence of NAA, making the plantlets more resistant, benefiting the system of in vitro production of seedlings of the species, as well as their conservation.

\section{Results}

\section{Physical attributes of the support materials}

Significant differences between the types of supports were observed for all physical attributes evaluated $(p<0.01)$. The queen palm F. support had the highest WD $\left(694.07 \mathrm{~kg} \mathrm{~m}^{-3}\right)$ and $\mathrm{DD}\left(507.56 \mathrm{~kg} \mathrm{~m}^{-3}\right)$ values, followed by vermiculite. Lower WD and DD values were observed for sugarcane B. of 466.55 and $364.67 \mathrm{~kg} \mathrm{~m}^{-3}$, respectively (Table 1 ).

Greater total porosity $\left(0.92 \mathrm{~m}^{3} \mathrm{~m}^{-3}\right)$ and aeration space $(0.35$ $\mathrm{m}^{3} \mathrm{~m}^{-3}$ ) were observed in the support material queen palm $F$. Lower values of these characteristics were observed in the support material vermiculite, with values of 0.57 and 0.15 $\mathrm{m}^{3} \mathrm{~m}^{-3}$, respectively. In sugarcane B., the TP was $0.73 \mathrm{~m}^{3} \mathrm{~m}^{-3}$, which was between the values detected for queen palm $\mathrm{F}$. and vermiculite. The AS of sugarcane B. was $0.12 \mathrm{~m}^{3} \mathrm{~m}^{-3}$ and did not differ from the value observed for vermiculite (Table $1)$.

Higher AW values were obtained for sugarcane B. $\left(0.38 \mathrm{~m}^{3}\right.$ $\left.\mathrm{m}^{-3}\right)$ and queen palm F. $\left(0.35 \mathrm{~m}^{3} \mathrm{~m}^{-3}\right)$, and lower RW values were observed in these two support materials: $0.23 \mathrm{~m}^{3} \mathrm{~m}^{-3}$ in sugarcane B. and $0.22 \mathrm{~m}^{3} \mathrm{~m}^{-3}$ in queen palm F. A lower AW value $\left(0.08 \mathrm{~m}^{3} \mathrm{~m}^{-3}\right)$ and higher RW value $\left(0.34 \mathrm{~m}^{3} \mathrm{~m}^{-3}\right)$ were detected in vermiculite (Table 1 ).

In vitro regeneration of $M$. elliptica (Mart.) plantlets in different culture medium support materials in the presence or absence of NAA

The growth patterns of the plantlets after 45 days of in vitro cultivation in culture medium support materials agar, sugarcane B., queen palm F. and vermiculite can be seen in
Fig $1(A-F)$. Greater plantlet length $(2.85 \mathrm{~cm})$ occurred in the agar culture, and shorter length $(1.69 \mathrm{~cm})$ occurred in the queen palm F. culture (Fig 2A). An increase of $86.66 \%$ in plantlet shoot length was seen when plantlets were grown in agar medium, with an initial explant length of $1.50 \mathrm{~cm}$ as the base. Increases in growth of $37.70,34.10$ and $13.00 \%$ were observed in the sugarcane B., vermiculite and queen palm F. cultures, respectively.

Differences between the support materials agar, vermiculite and sugarcane $B$. were not observed for the characteristics of number of nodal segments, number of leaves and total dry mass of plantlets (Fig 2B, C and D), and NAA did not influence these characteristics. An average of 1.44 nodal segments per plantlet was obtained in the agar culture, and averages of 0.92 and 0.67 were observed in vermiculite and sugarcane B., respectively (Fig $2 B$ ). A negative effect of NAA on growth was seen in sugarcane $B$., which had a higher number of nodal segments (1.25) in the absence of the regulator.

The averages observed for number of leaves in agar, vermiculite, and sugarcane B. were 4.5, 3.7 and 3.3, respectively. As observed for the characteristic number of nodal segments, a difference between the presence and absence of NAA for leaf regeneration was observed only in sugarcane B., where it was higher (4.0 leaves per plantlet on average) in the absence of the growth regulator (Fig $2 \mathrm{C}$ ). Regarding total dry mass, plantlets grown in agar, vermiculite and sugarcane $B$. had averages of $35.73,31.66$ and $26.59 \mathrm{mg}$, respectively. Smaller numbers of nodal segments (0.21) and numbers of leaves (2.41) and lower total dry mass $(23.00 \mathrm{mg}$ ) of plantlets were observed in the queen palm $\mathrm{F}$. culture (Fig 2B, C and D).

A higher number of adventitious roots (1.33), a longer main root $(5.66 \mathrm{~cm})$ and longer secondary roots (3.13) were observed in the vermiculite culture when the medium was devoid of NAA. Root formation was insignificant in the queen palm F. culture even in the presence of NAA. Among vermiculite, sugarcane $B$. and agar, there were no differences in these characteristics (Fig 3A, B, C).

Higher water content (71.64\%) was observed in plantlets produced in agar culture under increased NAA. There was no difference between the alternative support materials sugarcane B., queen palm F. and vermiculite, with averages of $61.41,59.58$ and $56.85 \%$, respectively (Fig 3D). Plantlet hyperhydricity was not observed in any support materials used.

Anatomical characteristics of roots formed in different culture medium support materials in the presence and absence of NAA

At the time of assessment (45 days of in vitro cultivation), many roots of the plantlets obtained in the agar culture without NAA broke during the measurement of length, thus, these roots were considered fragile (Fig $4 A$ and E). Visually, more resistant roots were formed in the vermiculite (Fig 4B) and sugarcane B. cultures (Fig 4D) in the absence NAA. No root formation occurred in the queen palm F. (Fig $4 C$ and G). Callus formation was obtained in vermiculite cultivation with addition of NAA (Fig 4F).

Roots with disorganized vascular cambium and no vascular cylinder and with predominant parenchymal tissue formed in plantlets grown in agar without NAA and in sugarcane B. 
Table 1. Physical characteristics of the alternative support materials used for in vitro cultivation of M. elliptica (Mart.) plantlets. Total porosity (TP), available water (AW), aeration space (AS), remaining water (RW), wet density (WD) and dry density (DD).

\begin{tabular}{lccc}
\hline \multirow{2}{*}{ Characteristics } & \multicolumn{3}{c}{ Support materials } \\
\cline { 2 - 4 } & Vermiculite & Sugarcane B. & Queen palm F. \\
\hline $\operatorname{TP}\left(\mathrm{m}^{3} \mathrm{~m}^{-3}\right)$ & $0.57 \pm 0.01 \mathrm{c}^{21}$ & $0.71 \pm 0.00 \mathrm{~b}$ & $0.93 \pm 0.01 \mathrm{a}$ \\
$\mathrm{AW}\left(\mathrm{m}^{3} \mathrm{~m}^{-3}\right)$ & $0.08 \pm 0.00 \mathrm{~b}$ & $0.38 \pm 0.02 \mathrm{a}$ & $0.35 \pm 0.03 \mathrm{a}$ \\
$\mathrm{AS}\left(\mathrm{m}^{3} \mathrm{~m}^{-3}\right)$ & $0.13 \pm 0.00 \mathrm{~b}$ & $0.12 \pm 0.01 \mathrm{~b}$ & $0.35 \pm 0.02 \mathrm{a}$ \\
$\mathrm{RW}\left(\mathrm{m}^{3} \mathrm{~m}^{-3}\right)$ & $0.34 \pm 0.00 \mathrm{a}$ & $0.23 \pm 0.01 \mathrm{~b}$ & $0.22 \pm 0.01 \mathrm{~b}$ \\
WD $\left(\mathrm{kg} \mathrm{m}^{-3}\right)$ & $654.13 \pm 2.73 \mathrm{~b}$ & $466.55 \pm 2.86 \mathrm{c}$ & $694.07 \pm 4.77 \mathrm{a}$ \\
$\mathrm{DD}\left(\mathrm{kg} \mathrm{m}^{-3}\right)$ & $493.83 \pm 1.82 \mathrm{~b}$ & $364.67 \pm 2.44 \mathrm{c}$ & $507.56 \pm 3.27 \mathrm{a}$ \\
\hline
\end{tabular}

${ }^{2}$ Means followed by the same letter in rows do not differ among according to the Tukey test at 0.05 significance. ${ }^{1} \pm$ Standard deviation from the mean.

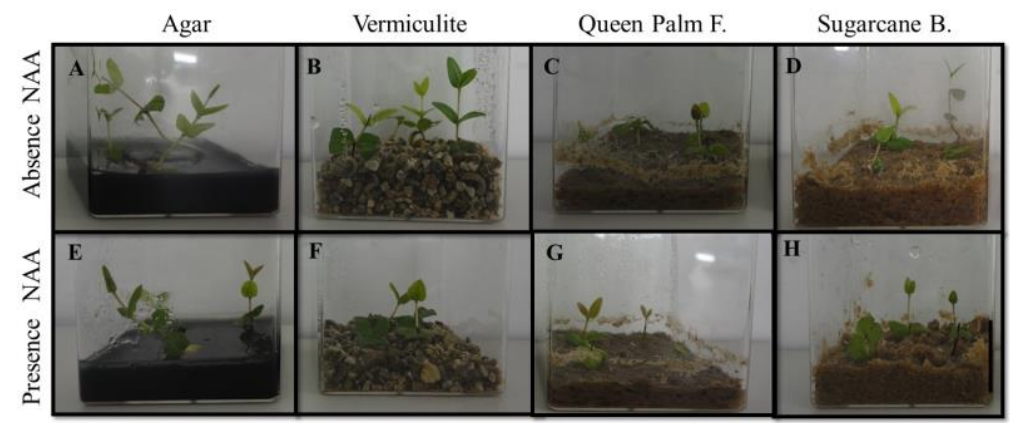

Fig 1. In vitro cultivation of Mouriri elliptica (Mart.) plantlets in different culture medium support materials for 45 days. Plantlet formed in different support materials in the absence or presence of Naphthalene Acetic Acid - NAA. Scale bar: $2 \mathrm{~cm}$.

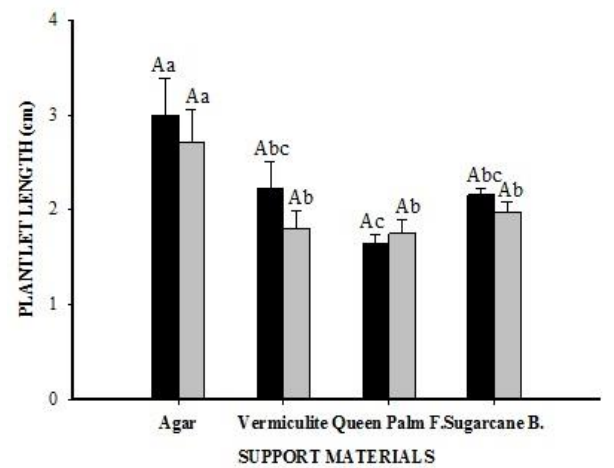

C

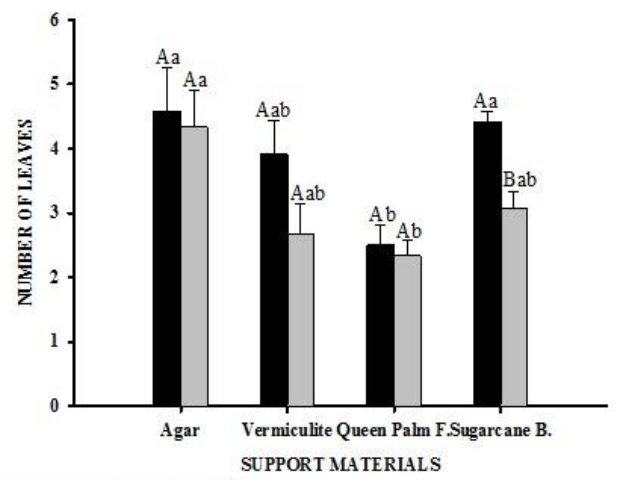

NAA: $0,0 \mathrm{mg} \mathrm{L}^{-1}$ NAA: $2,0 \mathrm{mg} \mathrm{L}^{-1}$
B

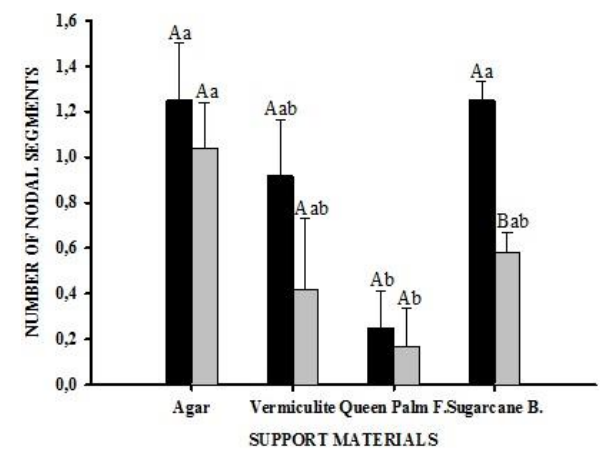

D

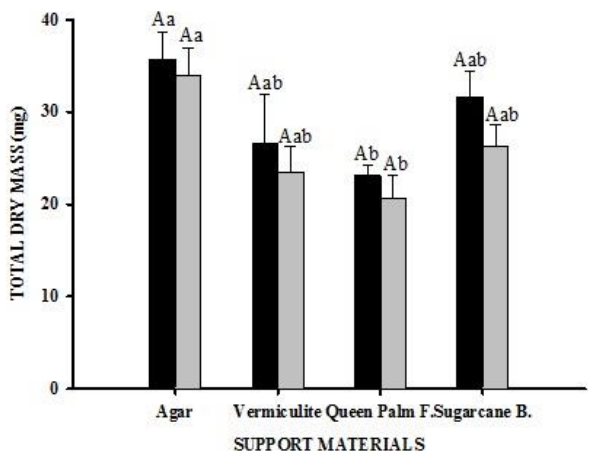

Fig 2. Length of plantlets (A), number of segments (B), number of leaves (C), and total dry mass (D) of $M$. elliptica (Mart.) plantlets with 45 days of in vitro cultivation. Means followed by the same uppercase letter do not differ between the presence and absence of NAA, and means followed by the same lowercase letter do not differ among support materials, according to the Tukey test at 0.05 significance. 
A

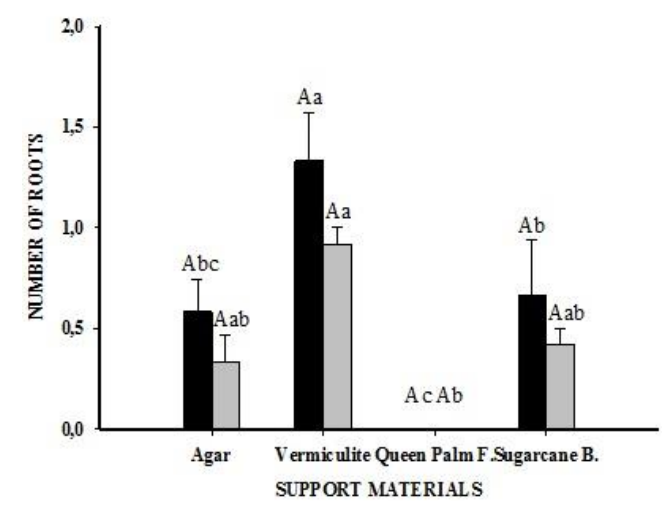

C

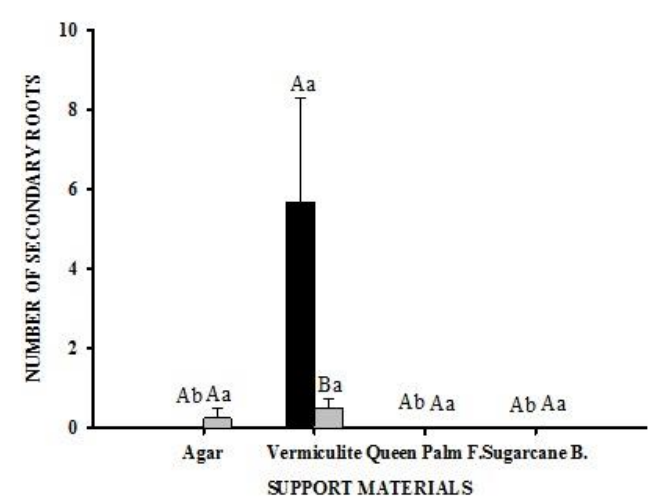

B

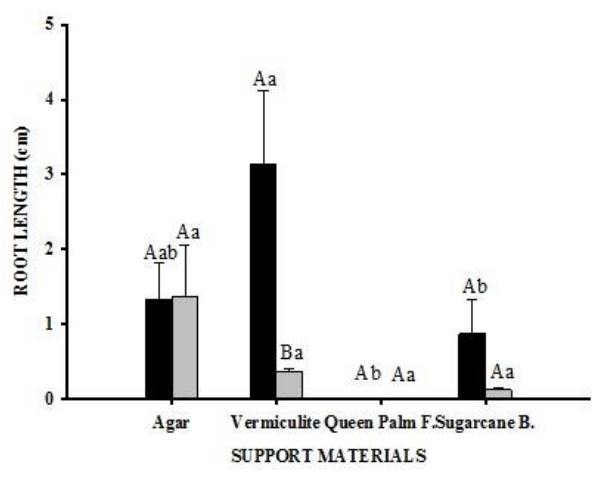

D

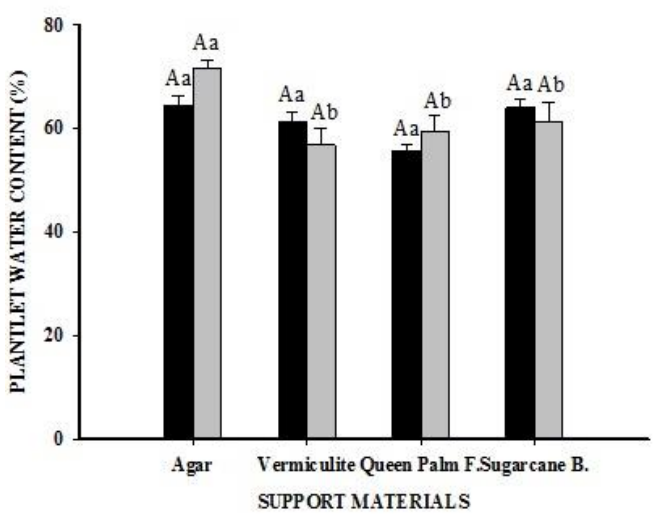

Fig 3. Number of roots (A), root length (B), number of secondary roots (C) and total water content (D) of M. elliptica (Mart.) plantlets with 45 days of in vitro cultivation. Averages followed by the same uppercase letter do not differ between the presence and absence of NAA, and averages followed by the same lowercase letter do not differ among support materials, according to the Tukey test at 0.05 significance.

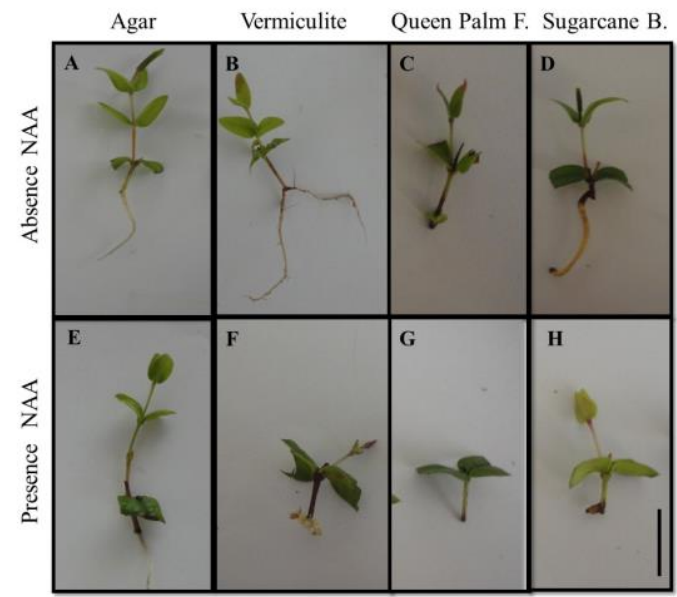

Fig 4. Mouriri elliptica (Mart.) plantlets with 45 days of in vitro cultivation. Plantlet formed in different support materials in the absence or presence of Naphthalene Acetic Acid - NAA. Scale bar $=2 \mathrm{~cm}$. 


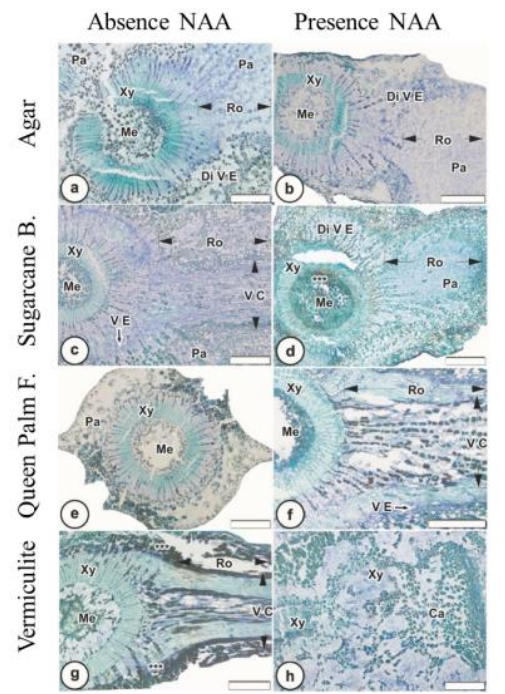

Fig 5. Anatomy roots Mouriri elliptica (Mart.) formad under in vitro culture for 45 days and, different support materials, being Agar $(a-b)$, Sugarcane bagasse (c-d), Queen palm fibers (e-f) and Vermiculute (g-h). Culture in the absence (letters a, c, e and g) or presence of Naphthalene Acetic Acid - NAA (letters b, $d$, $f$ and h). Parenchyma - Pa; xylem - Xy; root - Ro; medulla - Me; vascular cambium - V E; disorganized vascular cambium - Di V E; vascular cylinder - V C; callus - Ca and necrotic tissue $-* * *$. Scale bar $=$ $100 \mu \mathrm{m}$.

in the presence of the regulator (Fig 5A, B, D). Adventitious roots with differentiated tissues were obtained in the in vitro culture without growth regulator and using sugarcane B. (Fig $5 \mathrm{C}$ ) and vermiculite (Fig $5 \mathrm{G}$ ) as support material. A vascular cylinder connected to the vascular cambium of the stem was identified in these roots. This characteristic was also observed in roots of plantlets produced in the queen palm $\mathrm{F}$. culture when the medium was supplemented with NAA (Fig $5 F$ ). The growth regulator stimulated the formation of calluses at the base of segments of plantlets grown in vermiculite at a rate of $41.66 \%$. In Fig 4B, the morphological pattern of the callus at the base of the plantlet stems can be observed, and its internal organization can be observed in Fig $5 \mathrm{H}$. Disorganized tissues can be seen, but with a certain level of differentiation and the presence of xylem (Xy) (Fig $5 \mathrm{H})$.

\section{Discussion}

The results of this study demonstrate that vermiculite, followed by sugarcane B. can be used as agar substitutes in in vitro culture of M. elliptica (Mart.). This finding is based on the regeneration ability of seedling shoots and, in particular, root development. Woody plants are usually difficult to root, and thus, a material that facilitates in vitro rooting is beneficial in micropropagation systems by enabling the regulation of the growth environment based on the physical properties of the support material (Xiao et al., 2011).

Despite recommendations for the use of support materials, few studies have physically characterized these materials for use in vitro. The distribution of water, air and solids in alternative supports depends on several factors such as pore space, density, particle size and spatial distribution of pores (Oh et al., 2012). Such evaluations are common for use in nurseries, as the physical quality of the substrate is an important factor for seedling growth and development, providing nutrients, retaining water and moisture and being financially viable (Pagliarini et al., 2014).
Ideal substrates are those that promote better aeration and water infiltration and drainage. Vermiculite, followed by sugarcane B., provided good development of the seedlings under study for all evaluated characteristics. These supports had smaller pore spaces than queen palm $\mathrm{F}$. These results suggest that queen palm $F$. exerts a negative effect on seedling growth, particularly on root formation, even in the presence of NAA in the culture medium. Although queen palm F. did not promote good growth in the plantlets under study, it still has potential for in vitro use, as the response of plantlets is in part dependent on genotype. Different genotypes may respond differently to the same cultivation condition (Côrrea et al., 2015; 2016).

For growth of plants in containers, the best values for AW are between 0.24 and $0.40 \mathrm{~m}^{3} \mathrm{~m}^{-3}$ (De Boodt and Verdonck, 1972). For RW, the ideal range is between 0.25 and $0.30 \mathrm{~m}^{3}$ $\mathrm{m}^{-3}$ (Verdonck and Gabriëls, 1988). Although TP, AW and RW values outside of the ideal range for in vitro cultivation of plants in containers were observed in vermiculite, this support material allowed for better formation of adventitious and secondary roots and did not differ from agar and sugarcane B. in terms of shoot formation. The observed positive results reflect the ability of the seedlings to use the nutrient solution added to the vermiculite.

Our results demonstrate that the support material does not need to be excessively porous for proper root development of $M$. elliptica (Mart.) seedlings. In the case of vermiculite, a lower TP associated with a higher RW (water retained at matric potentials higher than $100 \mathrm{hPa}$ and present in the form of water films around the particles) resulting from the volumetric expansion of the mineral particles during their production promoted adequate gas exchange through the roots and provided greater substrate/root contact surface area, contributing to nutrient absorption processes and thus to plant growth and development.

Sugarcane B. had intermediate values for TP and AW and RW values within the ideal range (De Boodt and Verdonck, 1972; Verdonck and Gabriëls, 1988). For plantlet regeneration, it was less effective than vermiculite for root 
formation, although roots formed on plantlets grown in sugarcane B. formed differentiated tissues with a vascular cylinder connected to the vascular cambium of the stem, as also observed in roots formed in vermiculite. Roots formed in the agar culture, regardless of the presence or absence of NAA, were fragile and had poorly differentiated tissues and no secondary roots. Similar problems in root formation using agar have been reported and can cause problems in the acclimatization process (Braga et al., 2011).

The presence of NAA in the culture environment with vermiculite as the support material was a limiting factor in root formation, as the root length was shorter and the number of secondary roots was lower. In addition, a relatively high percentage of calluses was observed the base of the stem. This characteristic was considered undesirable in consideration of the principal objective of the study, the multiplication and rooting of M. elliptica (Mart.). However, this observation offers an opportunity to study callus formation from the stem of this species.

Thus, the characteristics of plantlets evaluated in this study informed the determination of physical attributes of alternative support materials to agar that were ideal for the in vitro cultivation of $M$. elliptica (Mart.) and that favored plantlet growth. However, studies on the micropropagation of this species using alternative support materials could be developed to evaluate the influence of other factors that typically promote development of more resistant plantlets, such as the elimination of sucrose in the culture medium, the use of gaskets that allow for increased gas exchange, the increase of light intensity and/or atmospheric enrichment with carbon dioxide $\left(\mathrm{CO}_{2}\right)$.

\section{Materials and methods}

\section{Collection of fruits, plantlets and explants, disinfection and inoculation}

Ripened fruits were harvest in mature plants of $M$. elliptica (Mart.) grown under natural conditions (in situ) November 2014, in the Planalto Verde District, municipality of Montividiu, Goiás, Brazil $\left(17^{\circ} 19.201^{\prime} S, 51^{\circ} 33.500^{\prime} \mathrm{W}\right.$ and 982 $\mathrm{m}$ in altitude). After harvest, seeds were treated according with Vasconcelos et al. (2010). Seedlings were obtained from seeds in trays with sand.

Plantlets with at least two axillary buds were used as explant sources, as they had nodal segments $1.5 \mathrm{~cm}$ in length. For the contamination control during in vitro culture the disinfection process followed, in which the explants were wrapped with gauze and placed under running water with three drops of neutral detergent for 15 minutes. In a laminar flow hood, the explants were immersed in $70 \%(\mathrm{v} / \mathrm{v})$ ethanol for 30 seconds and then submerged in $20 \%$ sodium hypochlorite - $\mathrm{NaOCl}$ solution (commercial bleach $2.0-2.5 \%$ active chlorine) for 15 minutes. To complete the disinfection, the explants were washed three times in distilled and autoclaved water.

The explants were subsequently inoculated into Magenta culture containers containing the alternative support materials or agar for plant culture. The alternative support materials studied were sugarcane bagasse (sugarcane B.) (Saccharum spp. L.), queen palm fiber (queen palm F.) [Syagrus romanzoffiana (Chamisso) Glassman] and mediumgrain vermiculite. The influence of the growth regulator naphthalene acetic acid (NAA) (Sigma) on plantlet rooting was also studied at concentrations of 0.0 and $2.0 \mathrm{mg} \mathrm{L}^{-1}$. The nutrient medium WPM (Wood Plant Medium, developed by Lloyd and McCown 1981) with $50 \%$ salts, $30 \mathrm{~g} \mathrm{~L}^{-1}$ sucrose, 3.5 $\mathrm{g} \mathrm{L}^{-1}$ agar (Dinâmica ) and $2 \mathrm{~g} \mathrm{~L}^{-1}$ activated carbon at (Synth ) was used, and a volume of $50 \mathrm{~mL}$ was used in each Magenta culture containers, which was sealed with a polypropylene closure. The $\mathrm{pH}$ of the growth medium was adjusted to $5.7 \pm$ 0.03 before autoclaving at $121^{\circ} \mathrm{C}$ for 20 minutes.

Five grams of alternative support materials was used in each Magenta culture containers. The volume of culture medium used was determined by calculating the amount of water to substrate (Brasil 2009), with some modifications. Thus, the support material $(5 \mathrm{~g})$ and the known volume of water (100 $\mathrm{mL}$ ) were placed in a funnel with filter paper and left to rest for 45 minutes to drain the water. The volume retained in the support material was used. Therefore, the volumes of liquid culture media used in $5 \mathrm{~g}$ of alternative support material were $41.0 ; 30.0$ and $21.3 \mathrm{~mL}$ for sugarcane B., queen palm $\mathrm{F}$. and vermiculite, respectively. Water loss through evaporation was measured every 3 days in flasks containing the alternative support materials without plant culture using an analytical balance. The observed water loss was $0.24 \mathrm{~mL} \mathrm{day}^{-1}$. The culture medium in each support material was replenished at 15 and 30 days of in vitro culture.

\section{Purification of sugarcane B. and queen palm F. support} materials for in vitro cultivation

To obtain the queen palm F., ripe fruits were placed in a fruit and vegetable depulper (Ker Mod. 1.5, Tortugan ) for 40 minutes to separate the epicarp and mesocarp (total pulp) from the diaspore (endocarp and seed). The dry sugarcane B. was derived from the Nova Gali ethanol plant located in Acreúna, Goiás, Brazil.

The fibrous support materials were washed in running water, using the methodology of Mohan et al. (2005) as a reference. For further purification of queen palm F., 10 consecutive washes with running water were necessary. Lastly, the fibrous material was washed 2 times with distilled water (heated to $95 \pm 5 \circ \mathrm{O}$ ).

Both queen palm $\mathrm{F}$. and sugarcane $\mathrm{B}$. were dried in an oven at $40^{\circ} \mathrm{C}$ for 72 hours and were then ground using a Willye (TE-650) grinder with a 5-mm sieve. Before using the supporting materials, including the vermiculite, they were washed with distilled water to remove ions. Afterwards, they were dried in an oven and autoclaved at 121 o $C$ for 20 min to contamination control.

\section{Physical characterization of the alternative support materials}

The physical characteristics of the alternative substrates were evaluated according to the recommendations of Zorzeto et al. (2014) and following the standard instructions established by the Brazilian Ministry of Agriculture, Livestock and Supply (Brasil, 2007), the official Brazilian government agency that regulates the use of substrates for plants destined for agriculture.

The wet bulk density (WD) was determined from the ratio of the mass occupied by the substrate to the volume at current moisture in a $250-\mathrm{cm}^{3}$ plastic beaker dropped under the 
action of its own weight from a height of $10 \mathrm{~cm}$ ten consecutive times (Brasil, 2008). After autocompaction, the samples were dried in an oven at $65^{\circ} \mathrm{C}$ to constant weight (Brasil, 2007), and the values were used to determine the dry bulk density (DD).

Other substrate samples were packed in PVC cylinders measuring $4 \mathrm{~cm}$ in diameter and $5 \mathrm{~cm}$ in height and subjected to saturation with distilled water for 24 hours at 10 to $100 \mathrm{hPa}$ to determine water retention curves (De Boodt and Verdonck, 1972; Brasil, 2008). The following parameters were determined: total porosity (TP), which considers the volumetric water content present in the saturated samples $(0 \mathrm{hPa})$; aeration space (AS), the difference between the total porosity and volumetric water content at $10 \mathrm{hPa}$; available water (AW), which corresponds to the volume of water between 10 and $100 \mathrm{hPa}$; and remaining water (RW), the amount of water remaining in the sample after it was subjected to $100 \mathrm{hPa}$ matric potential and equivalent to micropore water.

\section{Growth evaluations}

Evaluations were performed after 45 days of in vitro cultivation using the characteristics of plantlet length $(\mathrm{cm})$, number of nodal segments, number of leaves, total dry mass $(\mathrm{mg})$, numbers of adventitious and secondary roots, length of largest root $(\mathrm{cm})$ and water content of plantlets (\%). Measurements of length were obtained using a millimeter ruler.

To obtain the dry mass, the plant material remained in a ventilation oven forced to a temperature of $65 \stackrel{\circ}{\circ}$ for 72 hours, and weighing was performed on a digital analytical balance. The plantlet water content was determined from the difference between total fresh mass and total dry mass and was expressed as a percentage.

\section{Anatomical characteristics}

Four plantlets of M. elliptica (Mart.) submitted to the different types of culture were fixed in Karnovsky solution (Karnovsky, 1965) for 48 hours. The region of the stem with root formation was submitted to an embedding procedure, for which the samples were dehydrated in a graded ethylic series (30, 50, 70, 96 and 100\%), pre-infiltrated, infiltrated and polymerized in historesin (Historesin Leica, Erviegas Ltda: São Paulo - SP, Brazil) according to the recommendations of the manufacturer. Embedding molds were used to obtain polymerized blocks.

After drying, the blocks with plant material were cut into 5$\mu \mathrm{m}$-thick cross-sections in a rotary microtome (model RM 2155 , Leica). The sections were stained with toluidine blue dye $0.05 \%, \mathrm{pH} 4.0$ and were mounted on slides with Canada Balsam. Images were obtained with an Olympus model BX61 microscope with a DP-72 camera.

\section{Experimental design and statistical analysis}

The experiment was conducted in a completely randomized design (CRD) in factorial arrangement $(4 \times 2)$, with four types of support materials for the culture medium and the absence or presence of NAA. Four replications with three explants each per Magenta containers were performed for each factor studied. The data were subjected to analysis of variance (ANOVA), applying the $F$ test and the means were compared using the Tukey test ( $5 \%$ probability). SISVAR software (Ferreira, 2011) was used for the data analysis.

\section{Conclusion}

The alternative support materials vermiculite followed by sugarcane B. can be used as substitutes for agar for micropropagation of $M$. elliptica (Mart.). These support materials promoted shoot growth equal to that of agar and greater root formation and tissue differentiation, thus increasing the resistance of the plantlets and survival of the acclimatization process. The use of the growth regulator NAA did not stimulate increased rooting of $M$. elliptica (Mart.) plantlets in the types of support materials used in this study.

\section{Acknowledgments}

The authors thank the funding agencies the Research Support Foundation of the State of Goiás (Fundação de Amparo à Pesquisa do Estado de Goiás, FAPEG) and the Coordination for the Improvement of Higher Education Personnel (Coordenação de Aperfeiçoamento de Pessoal de Nível Superior, CAPES) for financial support.

\section{References}

Abdulmalik MM, Usman IS, Olarewaju JD, Aba DA (2012) Effect of naphthalene acetic acid (NAA) on in vitro rooting of regenerated microshoots of groundnut (Arachis hypogaea L.). Bayero J Pure and Appl Sci. 5(2):128-131.

Aggarwal S, Nirmala C (2012) Utilization of coir fiber as an eco-friendly substitute for costly gelling agentes for in vitro orchid seed germination. Sci Hort. 133(1):89-92.

Aina OO, Quesenberry KH, Gallo M (2015) Culture vessel and auxin treatments affect in vitro rooting and ex vitro survival of six Arachis paraguariensis genotypes. Sci Hort. 183(1):167-171.

Assis C, Pereira FD, Cabral JSR, Silva FG, Silva JW, Santos SC (2012) In vitro cultivation of Anacardium othonianum Rizz.: effects of salt concentration and culture medium volume. Acta Sci-Agronomy. 34(1):77-83.

Assis ES, Rubio Neto A, Lima LR, Silva FG, Rosa M, Vasconcelos Filho SC, Leite MS (2016) In vitro culture of Mouriri elliptica (Mart.) under conditions that stimulate photoautotrophic behavior. Aust J Crop Sci. 10(2):229-236.

Barpete S, Khawar KM, Özcan S (2014) Differential competence for in vitro adventitous rooting of grass pea (Lathyrus sativus I.). Plant Cell Tiss Organ Cult. 119(1):39-50.

Braga FT, Pasqual M, Castro EM Rafael GC (2011) Características morfofisiológicas de abacaxizeiro 'gomo de mel' enraizado in vitro sob luz natural e substrato vermiculita. Rev Bras Frutic. 33(2):551-557.

Brasil (2007). Ministério da Agricultura, Pecuária e Abastecimento - MAPA. Secretaria de defesa agropecuária. Instrução normativa no 17, de 21 de maio de 2007. Aprova os Métodos Analíticos Oficiais para Análise de Substratos e Condicionadores de Solos, na forma do Anexo à presente Instrução Normativa. Diário Oficial da República Federativa do Brasil. Seção 1, Brasília - Distrito Federal, p. 8 
Brasil (2008) Ministério da Agricultura, Pecuária e Abastecimento - MAPA. Secretaria de defesa agropecuária. Instrução normativa no 31 , de 23 de outubro de 2008. Altera os subitens 3.1.2, 4.1 e 4.1.2, do Anexo à Instrução Normativa SDA № 17, de 21 de maio de 2007. Diário Oficial da República Federativa do Brasil. Seção 1, Brasília - Distrito Federal, p. 20.

Brasil (2009). Regras para análise de sementes / ministério da agricultura, pecuária e abastecimento. Secretaria de defesa agropecuária. Mapa/ACS 200, Brasília.

Corrêa JPO, Vital C, Pinheiro MVMA, Batista DS, Azevedo JFL, Saldanha CW, Cruz ACF, DaMatta FM, Otoni WC (2015) in vitro photoautotrophic potential and ex vitro photosynthetic competence of Pfaffia glomerata (Spreng.) pedersen accessions. Plant Cell Tiss Organ Cult. 121(2):289-300.

Corrêa JPO, Vital C, Pinheiro MVMA, Batista DS, Saldanha CW, Cruz ACF, Notini MM, Freitas DMS, DaMatta FM, Otoni WC (2016) Induced polyploidization increases 20hidroxyecdysone content, in vitro photoautotrophic growth, and ex vitro biomass accumulation in Pfaffia glomerata (Spreng.) pedersen. In vitro cell and dev bio Plant. 52(1):45-55.

De Boodt M, Verdonck O (1972) The physical properties of the substrates in horticulture. Acta Hort. 26(1):37-44.

Deb C, Pongener A (2013) A study on the use of low cost substrata against agar for non-symbiotic seed culture of Cymbidium iridioides D. Don. Aust J Crop Sci. 7(5):642-649.

De Lima LR, Rubio Neto A, Pereira FD, Silva FG, De Menezes CCE, Santana JDG (2016). Germination and emergence of Mouriri elliptica Mart., a rare medicinal fruit tree native to the brazilian cerrado biome. Afr J Agric Res. 11(5):400-406.

Dornelles P, Silva FG, Mota CS, Santana JG (2014) Production and quality of Anacardium othonianum Rizz. seedlings grown in different substrates. Rev Bras Frutic. 6(2):479486.

Fagg CW, Lughadha EN, Milliken W, Hind N, Brandão MGL (2015) Useful brazilian plants listed in the manuscripts and publications of the scottish medic and naturalist george gardner (1812-1849). J Ethnopharmacol. 161(1):18-29.

Ferreira DF (2011) Sisvar: a computer statistical analysis system. Ciênc Agrotec. 35(6):1039-1042.

Hossain S, Urbi Z (2016) Effect of naphthalene acetic acid on the adventitious rooting in shoot cuttings of Andrographis paniculata (Burm.F.) wall. ex nees: an important therapeutical herb. Int J Agron. ID 1617543, 6 p.

Karnovsky MJ (1965). A formaldehyde-glutaraldehyde fixative of high osmolality for use in electron microscopy. J Cell Biol. 27(2):1A-149A.

Lloyd G, Mccown B (1981) Commercially feasible micropropagation of montain laurel, kalmia latifolia, by use of shoot tip culture. Int Plant Prop Society Proceedings. 30(5):421-427.

Mali AM, Chavan NS (2016) In vitro rapid regeneration through direct organogenesis and ex-vitro establishment of Cucumis trigonus Roxb. an underutilized pharmaceutically important cucurbit. Ind Crops Prod. 83(1):48-54.

Martendal CO, Bernardino MM, Pereira FD, Silva FG, Menezes CCE, Santana JG (2014) In vitro multiplication of nodal segments of "murici" (Byrsonima cydoniifolia A Juss.): the use of growth regulators and photoautotrophic stimulation. J Agricultural Technology. 10(3):665-678.

Mohan R, Chui EA, Biasi LA, Soccol CR (2005) Alternative in vitro propagation: use of sugarcane bagasse as a low-cost support material during rooting stage of strawberry $\mathrm{cV}$ Dover. Braz Arch Biol Technol. 48:37-42.

Moleiro FC, Andreo MA, Santos RdeC, Moraes TdeM, Rodrigues CM, Carlis CB, Lopes FC, Pellizzon CH, Carlos IZ, Bauab TM, Vilegas W, Hiruma-Lima CA (2009) Mouriri elliptica: validation of gastroprotective, healing and antihelicobacter pylori effects: validation of gastroprotective, healing and anti-helicobaster pylori effects. J Ethnopharmacol. 123(1):359-368.

Navarro-García N, Morte A, Pérez-Tornero O (2016) In vitro adventitious organogenesis and histological characterization from mature nodal explants of Citrus limon. In Vitro Cell Dev Biol. 52(2):161-173.

Oh MM, Seo JH, Park JS, Son JE (2012) physicochemical properties of mixtures of inorganic supporting materials affect growth of potato (Solanum tuberosum I.) plantlets cultured photoautotrophically in a nutrient-circulated micropropagation system. Hort Environ and Biotechnol. 53(6):497-504.

Pagliarini MK, Castilho RMM, Alves MC (2012) Caracterização físico-química de misturas de componentes de substrato com resíduo de celulose para fins de produção de mudas. Rev Bras Agroecol. 7(2):160-169.

Patel AK, Phulwaria M, Rai MK, Gupta AK, Shekhawat S, Shekhawat NS (2014) In vitro propagation and ex vitro rooting of caralluma edulis (edgew.) benth. and hook. f.: an endemic and endangered edible plant species of the thar desert. Sci Hortic. 165(1):175-180.

Rufino MSM, Alves RE, Fernandes FAN, Brito ES (2011) Free radical scavenging behavior of ten exotic tropical fruits extracts. F Res International. 44(7):2072-2075.

Saldanha CW, Otoni CG, Rocha DI, Cavatte PC, Detmann KSC, Tanaka FAO, Dias LLC, DaMatta FM, Otoni WC (2014). $\mathrm{CO}_{2-}$ enriched atmosphere and supporting material impact the growth, morphophysiology and ultrastructure of in vitro brazilian-ginseng [Pfaffia glomerata (Spreng.) Pedersen] plantlets. Plant Cell Tiss Organ Cult. 18(1):87-99.

Shekhawat MS, Manokari M (2016) In vitro regeneration frequency, micro-morphological studies and ex vitro rooting of Hemidesmus indicus (I.) r. br.: a multipotent endagered climber. Indian J of Plant Physiology. 21(2):151160.

Vasconcelos JM, Cardoso TV, Sales JF, Silva FG, Vasconcelos Filho SC, Santana JG (2010) Métodos de superação de dormência em sementes de croada (Mouriri elliptica Mart.). Ciênc Agrotec. 34(5):1199-1204.

Verdonck O, Gabriëls R (1988) Substrate requirements for plants. Acta Hort. 221(1):19-23.

Xiao Y, Niu G, Kozai T (2011) Development and application of photoautotrophic micropropagation plant system. Plant Cell Tiss Organ Cult, 105(2):149-158.

Zorzeto TQ, Dechen SCF, Abreu MF, Júnior FF (2014) Caracterização física de substratos para plantas. Bragantia. 73(3):300-311. 